https://doi.org/10.18778/7525-598-0.15

\title{
Patrycja Sokołowska
}

\section{Problemy implementacji cywilnych aspektów Porozumienia z Dayton na przykładzie aktywności Wysokiego Przedstawiciela oraz Unii Europejskiej}

Od zakończenia wojny społeczność międzynarodowa aktywnie angażuje się w proces budowy pokoju i stabilizacji Bośni i Hercegowiny $(\mathrm{BiH})$, podejmując szereg działań mających na celu stworzenie sprawnie funkcjonujących instytucji państwowych, demokratyzację oraz wsparcie rozwoju tego państwa na drodze do Unii Europejskiej (UE) i NATO. Wraz z podpisaniem pokoju z Dayton szczególną rolę w tym regionie przejęły: Sojusz Północnoatlantycki, Organizacja Narodów Zjednoczonych, Organizacja Bezpieczeństwa i Współpracy w Europie, Unia Europejska oraz szereg innych organizacji międzynarodowych i pozarządowych, realizujących różnego rodzaju programy pomocowe. Jednak, mimo ogromnej pomocy międzynarodowej, Bośnia nie jest w pełni samodzielnie i sprawnie funkcjonujaccym państwem. W sprawozdaniu Komisji Europejskiej z 2010 r. BiH uzyskała jak dotychczas najgorszą ocenę swoich postępów na drodze do UE. Jednocześnie pojawiły się hasła wystapienia Republiki Serbskiej (RS) z konfederacji, a sam system polityczny, stworzony na mocy Porozumienia z Dayton, uniemożliwia przeprowadzenie reform na szczeblu ogólnopaństwowym tak, aby wzmocnić działanie instytucji centralnych. Przyczyn tego rodzaju sytuacji upatruje się nie tylko w braku dobrej woli wśród lokalnych elit politycznych, ale coraz częściej także w niespójnej polityce społeczności międzynarodowej. W tym też kontekście długoletnia aktywność różnego rodzaju organizacji nasuwa pytanie o ich skuteczność w procesie utrzymania pokoju i stabilizacji tego regionu. Celem niniejszego opracowania jest więc próba oceny efektywności działań na rzecz implementacji cywilnych zapisów Porozumienia z Dayton, identyfikacja błędów, jak również analiza przyczyn tego stanu rzeczy. Ze względu na zakres zagadnienia, niemożliwe jest uwzględnienie w poniższym artykule wszystkich organizacji międzynarodowych działających w Bośni i Hercegowinie. Biorąc jednak pod uwagę znaczenie instytucji uwzględnionych w zapisie Porozumienia z Dayton, autorka postanowiła przeanalizować poszczególne problemy na przykładzie działalności urzędu Wysokiego Przedstawiciela (HR) oraz UE. Szczególnej analizie zostanie poddane zaangażowanie Unii. Nie ulega bowiem wątpliwości, iż za główny cel strategiczny stawia sobie osiagnięcie wysokiego stopnia demokratyzacji i stabilizacji poszczególnych państw, w oparciu o użycie zintegrowanego 
systemu wzajemnie się uzupełniających komponentów cywilnych i wojskowych oraz silne zaangażowanie się w rozbudowę systemu prewencyjnego zapobiegania konfliktom, tak w wymiarze wewnętrznym (integralności państwa i jego struktur), jak i zewnętrznym (ekonomicznej i politycznej integracji Bośni ze strukturami euroatlantyckimi).

\section{Biuro Wysokiego Przedstawiciela - charakterystyka mandatu}

Zgodnie z aneksem nr 10 do Porozumienia z Dayton, w celu realizacji postanowień pokojowych powołano Wysokiego Przedstawiciela wraz z jego Biurem (OHR), delegowanego przez Radę Bezpieczeństwa ONZ. Jego zadaniem jest monitorowanie, kontrolowanie oraz zapewnienie pomocy $\mathrm{w}$ czasie realizacji postanowień Porozumienia. W ramach swoich kompetencji ma on koordynować działania organizacji i agencji cywilnych w Bośni i Hercegowinie, w celu zapewnienia skutecznej realizacji cywilnych aspektów wspomnianego dokumentu. Wysoki Przedstawiciel, mimo że jest zobowiązany do poszanowania autonomii poszczególnych organizacji, to w sytuacjach wyższej konieczności może wydawać ogólne wskazówki na temat wpływu ich działań na realizację Porozumienia. Natomiast organizacje i agencje cywilne powinny wspierać Wysokiego Przedstawiciela w realizacji jego obowiązków oraz dostarczać mu wszelkich informacji o swojej działalności, istotnych dla funkcjonowania jego mandatu ${ }^{1}$. Dodatkowo Aneks nr 10 za najważniejsze zadania Wysokiego Przedstawiciela uznaje: niesienie pomocy humanitarnej, utrzymywanie kontaktów z obiema częściami państwa, udział w powstaniu konstytucyjnych instytucji państwa, ochronę oraz propagowanie praw człowieka, przeprowadzenie wolnych wyborów oraz rozwiazanie problemu uchodźców i osób przesiedlonych². Wysoki Przedstawiciel pełni również funkcję reprezentanta społeczności międzynarodowej na terenie powojennej Bośni i Hercegowiny. Jednocześnie Federacja Bośni i Hercegowiny, jak i Republika Serbska, zobowiązały się do aktywnej współpracy z nim. Ma on dostarczać wskazówek komisarzowi z Międzynarodowych Sił Policyjnych ONZ, określonych w załączniku nr 11 do Ogólnej umowy ramowej. Dodatkowo Wysoki Przedstawiciel, lub wyznaczona przez niego osoba, pozostaje w bliskim kontakcie z Dowództwem Sił Implementacyjnych NATO (IFOR). Wspólnie przyjmuja ustalenia odnośnie do współpracy, mającej ułatwić im wykonywanie swoich zadań. Obie strony zobowiązane są również do wymiany informacji. Wysoki Przedstawiciel bierze udział w posiedzeniach Wspólnej Komisji Wojskowej

1 The General Framework Agreement, 14 XII 1995, Aneks 10, art. 2, http://www.ohr.int/ dpa/default.asp?content_id=366 (dostęp 20 II 2011).

${ }_{2}$ Tamże, art. 1. 
i oferuje doradztwo w sprawach o charakterze polityczno-wojskowym. Nie ma on jednak zwierzchności nad wojskami IFOR i nie może w żaden sposób ingerować w prowadzenie operacji wojskowych ${ }^{3}$.

Zgodnie z Aneksem nr 10 Porozumienia z Dayton Biuro Wysokiego Przedstawiciela ma status misji dyplomatycznej w $\mathrm{BiH}$, tworzonej przez przedstawicieli państw delegowanych do Rady do spraw Wdrażania Pokoju (PIC), międzynarodowych ekspertów oraz pracowników lokalnych. OHR jest finansowane przez PIC. Przykładowo jego budżet w latach 2008-2009 wyniósł 11,3 mln euro, z czego $53 \%$ to wkład UE, $22 \%$ - Stanów Zjednoczonych, 10\% - Japonii, 4\% - Rosji, 3\% Kanady i 5\% innych państw. Sama PIC powstała podczas spotkania w Londynie w dniach 8-9 grudnia 1995 r. Jej celem jest wsparcie Porozumienia z Dayton. PIC tworzy pięćdziesiąt pięć państw i instytucji, a jej organem wykonawczym jest Rada Zarządzająca - Steering Board - która przedstawia kandydaturę Wysokiego Przedstawiciela oraz udziela mu wskazówek podczas tygodniowych spotkań na szczeblu ambasadorów. Członkami Steering Board sa: Kanada, Francja, Niemcy, Włochy, Japonia, Rosja, Wielka Brytania, USA, UE oraz Organizacja Konferencji Islamskiej, reprezentowana przez Turcję.

Jednym z decydujących wydarzeń, które wpłynęły na funkcjonowanie urzędu Wysokiego Przedstawiciela, była konferencja PIC w Bonn w grudniu 1997 r. Wobec braku postępów w realizacji postanowień Porozumienia z Dayton opracowała ona wówczas, na podstawie załącznika nr 10 do Porozumienia Pokojowego z Dayton, nowe kompetencje dla Wysokiego Przedstawiciela, które przyjęły się pod nazwą „uprawnienia bońskie” (Bonn powers). Odtąd mógł on usuwać urzędników łamiących zobowiązania prawne i zapisy z Dayton oraz narzucać ustawy, jeśli organy państwowe nie były w stanie samodzielnie stanowić prawa ${ }^{4}$. I mimo iż jedna z zasad regulujących działanie HR jest koncepcja krajowej odpowiedzialności, polegająca na przekazywaniu obywatelom Bośni odpowiedzialności za problemy funkcjonowania państwa oraz dalszy proces pokojowy ${ }^{5}$, to podczas spotkania w Bonn ustalono, iz to HR jest najwyższą instancją w zakresie interpretacji cywilnych postanowień Porozumienia z Dayton ${ }^{6}$. W ten sposób stał się on jednym z najważniejszych źródeł prawa w Bośni i Hercegowinie. Przykładem zastosowania powyższych uprawnień w latach 1998-2002 były następujące decyzje: rozwiązanie parlamentu RS (1998 r.); zdymisjonowanie prezydenta RS Nikoli Poplašena (marzec 1999 r.); narzucenie Republice Serbskiej oraz Federacji Bośni i Hercegowiny symboli narodowych, takich jak: hymn, flaga i godło, które miały stać się

\footnotetext{
${ }^{3}$ Tamże, art. 2 . 2011).

4 The Mandat of the OHR, http://www.ohr.int/ohr-info/gen-info/\#pic (dostęp $13 \mathrm{II}$

${ }^{5}$ Tamże.

${ }^{6}$ PIC Bonn Conclusions, 10 XII 1997, http://www.ohr.int/pic/default.asp?ontent_id= 5182 (dostęp 12 II 2011).
} 
elementami nowej tożsamości państwowej poszczególnych podmiotów konfederacji $\mathrm{Na}$ mocy jego decyzji w 2000 r. rozstrzygnięto status spornej enklawy Brčko i stworzono w tym miejscu odrębny podmiot o nazwie Dystrykt Brčko. Tym samym też została zmieniona polityczna i terytorialna organizacja państwa i pojawił się trzeci podmiot, mimo że konstytucja z 1995 r. mówi, że BiH składa się z dwóch entitetów $^{8}$. Na mocy jego decyzji powstały też takie instytucje, jak: Państwowa Agencja Śledcza i Ochronna (SIPA) czy Ministerstwo Bezpieczeństwa. W czerwcu 2004 r. Wysoki Przedstawiciel, w osobie Paddy Ashdowna, zdymisjonował jednorazowo sześćdziesięciu wysokich urzędników w Republice Serbskiej.

\section{Delegacja UE w Bośni i Hercegowinie}

Od początku konfliktu w Bośni i Hercegowinie UE angażuje się w stabilizację tego państwa. Nie ulega wątpliwości, iż Unia dzięki swojemu politycznocywilno-militarnemu zaangażowaniu stała się jednym $\mathrm{z}$ głównych aktorów międzynarodowych w BiH i odgrywa tam ważną rolę w rozwoju demokracji i praworządności. Przez ostatnie piętnaście lat Bruksela stosowała tam wszelkie możliwe mechanizmy, w tym także instytucjonalne, aby pomóc Bośni w osiaganiu stabilizacji i w przygotowaniu jej do stopniowej integracji z Unią Europejską ${ }^{10}$. Jednym z nich jest delegacja UE w Sarajewie powołana w dniu 8 lipca 1996 r. jako Delegacja Komisji Europejskiej. Wraz z wejściem w życie Traktatu Lizbońskiego z dniem 1 grudnia 2009 r., zmieniła ona nazwę na Delegacja Unii Europejskiej, a jej podstawowe zadania to prezentacja i wdrażanie polityki Brukseli w Bośni i Hercegowinie. Delegacja UE funkcjonuje w oparciu o tworzenie porozumien, promowanie interesów będących odzwierciedleniem polityki zagranicznej i bezpieczeństwa, polityki rolnej, ekologicznej i zdrowia UE. Zajmuje też kluczową pozycję w udzielaniu pomocy finansowej, a głównym jej celem jest wsparcie Bośni w Procesie Stabilizacji i Stowarzyszenia (SAP). W latach 20002006 Delegacja przeznaczyła dla BiH ze środków CARD 4,5 mln euro. Zostały one wykorzystane do budowy instytucji państwowych oraz realizacji programów obliczonych na pojednanie i powrót uchodźców. Dodatkowo z sumy tej finansowa-

${ }^{7}$ W. Stanisławski, Bośnia i Hercegowina wobec pytania o tożsamość, „Prace OSW” 2003 , nr 10, s. 9 .

${ }^{8}$ S. Gavirć, D. Banović, Constitutional Reform in Bosnia and Herzegovina, „Südosteuropa Mitteilungen" 2010, Heft 1, s. 67.

${ }^{9}$ W. Stanisławski, M. Szpala, Bośniacki chaos. Źródła kryzysu politycznego we wspótczesnej Bośni i Hercegowinie, „Prace OSW” 2009, nr 31, s. 23.

${ }^{10}$ UE motorem reform w Bośni i Hercegowinie, wywiad z Valentinem Inzko, Specjalnym Przedstawicielem UE w Bośni i Hercegowinie, http://www.consilium.uropa.eu/show Focus.aspx?id=1\&focusId=394\&lang=PL (dostęp 14 II 2011). 
no rozwój porządku instytucjonalnego i legislacyjnego państwa, włącznie z dopasowaniem $\mathrm{BiH}$ do standardów europejskich w zakresie wdrożenia demokracji i porządku prawnego, jak również poszanowania praw człowieka oraz kształtowania społeczeństwa obywatelskiego. Bruksela wydzieliła także odpowiednie środki na projekty mające na celu przyspieszenie rozwoju ekonomicznego kraju i wzmocnienie jego struktur społecznych. Dodatkowo wspiera współpracę regionalną oraz z państwami UE. Począwszy od 2007 r. wprowadzono Instrument Pomocy Przedakcesyjnej (IPA), który zastapił wcześniejsze, przedakcesyjne programy PHARE, ISPA, SAPHARD oraz CARD ${ }^{11}$.

\section{Specjalny Przedstawiciel UE}

W lutym 2002 r. Bruksela mianowała Wysokiego Przedstawiciela Specjalnym Przedstawicielem Unii Europejskiej w Bośni i Hercegowinie (EUSR). Jego zadaniem jest koordynacja działań politycznych UE w tym państwie, zapewnienie spójności pomiędzy różnymi instrumentami unijnej polityki zagranicznej i działaniami Komisji, a także wspieranie inicjatyw na rzecz reformy systemu prawnego. Dodatkowo pełni on funkcję doradczą w procesie wdrażania reformy policji, która została zapoczątkowana przez ONZ, a następnie jest kontynuowana przez UE. Rola EUSR w żadnej mierze nie ogranicza mandatu Wysokiego Przedstawiciela w Bośni i Hercegowinie ${ }^{12}$.

\section{Misja Policyjna Unii Europejskiej}

Oprócz realizacji szeregu programów pomocowo-rozwojowych UE jest aktywnym uczestnikiem cywilnych oraz wojskowych misji pokojowych, których głównym celem pozostaje stabilizacja struktur państwowych Bośni i Hercegowiny. Jedna z nich to rozpoczęta w dniu 1 stycznia 2003 r. Misja Policyjna Unii Europejskiej (EUPM). Do jej głównych zadań należy: szkolenie, doradztwo i reforma policji, poprawa jej efektywności operacyjnej oraz wzmacnianie profesjonalizmu funkcjonariuszy o wyższych stopniach i pracowników z wyższych szczebli struktury państwowej. Ponadto ma ona na celu wspieranie istniejących

${ }^{11}$ The EU and BiH. Main Objectives of Assistance, http://www.delbih.ec.europa.eu/ ?akcija $=$ clanak\&CID=8\&jezik=2\&LID=23 (dostęp 25 II 2011).

${ }^{12}$ Council Joint Action of 11 March 2002 on the Appointment of the EU Special Representative in Bosnia and Herzegovina, (2002/211/CFSP), http://eur-lex.europa.eu/Notice.do? val=272995:cs\&lang=pl\&list=272996:cs, 272995:cs, 272994:s, $272981: c s, \& p o s=2 \& p a g e=1 \& n b l$ $=4 \&$ pgs $=10 \&$ hwords $=\&$ checktexte=checkbox\&visu=\#texte $($ dostęp 12 II 2011). 
na terenie Bośni instytucji odpowiadających za bezpieczeństwo oraz zwalczanie przestępczości zorganizowanej i monitorowanie funkcjonowania politycznej kontroli nad policją ${ }^{13}$. Początkowo misja została ustanowiona na okres trzech lat, jednak w związku z brakiem postępów przy reformie policji oraz ze względu na problemy przy zwalczaniu przestępczości zorganizowanej, została ona przedłużona do końca 2011 r. ${ }^{14}$

\section{EUFOR „Althea”- misja pokojowa Unii Europejskiej}

Misja pokojowa Sił Unii Europejskiej „Althea” (EUFOR „Althea”) jest jednym z militarnych przejawów obecności UE w Bośni i Hercegowinie i tym samym częścia spójnego podejścia do stabilizacji i wsparcia reform w tym państwie. EUFOR jest pierwszą misją UE prowadzona na mocy porozumienia Berlin-Plus, które oznacza, iż przy prowadzeniu operacji militarnych może ona korzystać z zasobów NATO. Misja została powołana na mocy Rezolucji Rady Bezpieczeństwa ONZ nr 1575 z 2004 r., zastępując tym samym SFOR. Swoje działania rozpoczęła w dniu 2 grudnia 2004 r., z chwilą przejęcia przez UE dowództwa nad stacjonującymi w Bośni i Hercegowinie siłami stabilizacyjnymi NATO. Kontyngent działajacy w ramach operacji EUFOR „Althea” liczył w momencie rozpoczęcia operacji 6,5 tys. żołnierzy. Do ich głównych zadań na terenie Bośni należało: zabezpieczenie realizacji postanowień pokojowych z Dayton, czuwanie nad bezpieczeństwem $\mathrm{w}$ regionie, przejmowanie i niszczenie broni, rozminowywanie terenu, zwalczanie zorganizowanej przestępczości, zapobieganie przemytowi broni i narkotyków oraz ściganie zbrodniarzy wojennych. Ze względu na wyraźną poprawę poziomu bezpieczeństwa w Bośni i Hercegowinie, Unia Europejska podjęła 27 lutego 2007 r. decyzję o stopniowej redukcji sił uczestniczących w operacji EUFOR. W konsekwencji zostały one zredukowane do liczby 2,5 tys. żołnierzy. Jednocześnie przeprowadzono zmianę zasad realizacji operacji, która odtąd składa się z trzech komponentów. Zlikwidowano szczebel Wielonarodowych Sił Zadaniowych, a w ich miejsce utworzono Wielonarodowy Batalion Manewrowy w Sarajewie (MNBN). W skład struktury operacyjnej kontyngentu wchodzi czterdzieści pięć Zespołów Obserwacyjno-Łącznikowych (LOTs), które sa swego rodzaju „oczami i uszami” dowódcy operacji w różnych regionach Bośni. Kolejny element to Zintegrowane Jednostki Policji (IPU), w sile około 500 osób, złożone

${ }_{13}$ Council Joint Action of 11 March 2002 on the European Union Police Mission, http://ue.eu.int/uedocs/cmsUpload/Joint\%20Action\%202002\%20210\%20CFSP.pdf (dostęp 12 II 2011).

${ }_{14}$ Zob. P. Sokołowska, Bilans działalności Misji Policyjnej Unii Europejskiej w Bośni $i$ Hercegowinie, „Rocznik Bezpieczeństwa Międzynarodowego” 2009/2010, s. 110-126. 
głównie z włoskich karabinierów. W ten sposób misja wojskowa UE w Bośni i Hercegowinie stała się namacalnym dowodem na praktyczne funkcjonowanie „drugiego filaru” Wspólnoty Europejskiej oraz przykładem ich współpracy z NATO ${ }^{15}$.

Po przejęciu misji przez UE długoterminowe zaangażowanie NATO w Bośni i Hercegowinie pozostało bez zmian, a Kwatera Główna w Sarajewie stanowi namacalny dowód obecności wojskowej w tym kraju. Głównym jej zadaniem jest pomoc $\mathrm{w}$ przeprowadzaniu reformy wojskowej państwa oraz przy wypełnianiu przez nie kryteriów uczestnictwa w programie Partnerstwo dla Pokoju i członkostwa w NATO. Dodatkowo Kwatera Główna Sojuszu Północnoatlantyckiego w Sarajewie prowadzi działania o charakterze operacyjnym, obliczone na zwalczanie terroryzmu oraz wsparcie działań Międzynarodowego Trybunału Karnego dla byłej Jugosławii16.

\section{Problemy w koordynacji działań i wyznaczeniu} jednolitej strategii spoleczności międzynarodowej

Po podpisaniu pokoju w 1995 r. społeczność międzynarodowa stanęła przed ogromnym wyzwaniem, jakim była implementacja Porozumienia z Dayton. Przedsięwzięcie to było o tyle trudne, iż wymagało koordynacji działań różnorodnych aktorów, państw i instytucji międzynarodowych. Już na samym początku pierwsi Wysocy Przedstawiciele, nie dysponując władzą wykonawcza, mieli ograniczone możliwości wywierania nacisku na strony konfliktu oraz koordynowania pracy różnorodnych instytucji międzynarodowych. Nie posiadając zwierzchności nad IFOR, byli też uzależnieni od dobrej woli ich dowództwa, co w konsekwencji - mimo obecności 60 tys. wojsk międzynarodowych oraz 2 tys. policjantów ONZ - nie doprowadziło do osiagnięcia stanu bezpieczeństwa i stabilizacji ${ }^{17}$. Wraz z umocnieniem pozycji HR poprzez wprowadzenie „uprawnień bońskich" w 1997 r., zauważyć można pewne postępy w implementacji cywilnych aspektów Porozumienia z Dayton. Podczas rządów Wysokich Przedstawicieli: Carlosa Westendorpa (od czerwca 1997 r. do sierpnia 1999 r.) oraz Wolfganga Petritscha (od sierpnia 1999 r. do maja 2002 r.), Biuro Wysokiego Przedstawiciela naciskało na wprowadzenie środków niezbędnych do zagwarantowania powrotu uchodźców oraz ustanowienia systemu rządów prawa. Westendorp nie tylko

15 Zob.: taż, Polityka zagraniczna i bezpieczeństwa RFN wobec państw obszaru byłej Jugostawii w latach 1990-2005, Toruń 2010, s. 343-345.

${ }_{16}$ What is NATO HQ Sarajevo, http://www.jfcnaples.nato.int/hqsarajevo/page5347 431.aspx (dostęp 22 II 2011).

${ }_{17}$ C. Friesendorf, The Military and Law Enforcement in Peace Operations. Lessons from Bosnia-Herzegovina and Kosovo, Berlin 2010, s. 38-39. 
wprowadził jednolite tablice rejestracyjne oraz paszporty, ale także wspólną flagę, walutę i prawo telekomunikacyjne. Natomiast W. Petritsch doprowadził do przyjęcia $\mathrm{w}$ obu entitetach tych samych zapisów prawa $\mathrm{w}$ zakresie ochrony własności prywatnej, co było konieczne, aby przezwyciężyć opory uchodźców przed powrotem. Paddy Ashdown, który sprawował swój urząd w okresie od maja 2002 r. do stycznia 2006 r., dążył do ożywienia gospodarki oraz koncentracji działań na rzecz ewentualnego członkostwa w NATO i UE. Podją się próby przeprowadzenia reformy policji oraz skutecznie zabiegał o stworzenie wspólnej armii. Dotychczas bowiem Bośnia i Hercegowina nie miała wspólnych struktur wojskowych na szczeblu centralnym, a kontrolę nad poszczególnymi formacjami sprawowały władze poszczególnych entitetów ${ }^{18}$.

Od 1995 r. działania społeczności międzynarodowej charakteryzowały się jednak daleko idącą niekonsekwencją i brakiem przemyślanej strategii. W okresie 1997-2006 społeczność międzynarodowa, w tym osoby sprawujące urząd HR, majac pełne poparcie PIC, starała się realizować postanowienia z Dayton, dotyczace budowy przejrzystych i funkcjonalnych instytucji państwowych, poprzez prowadzenie polityki twardej ręki i wywieranie stałego nacisku na władze entitetów. W wyniku tego rodzaju podejścia P. Ashdown m.in. zdymisjonował kilkudziesięciu ważniejszych urzędników państwowych Bośni i Hercegowiny na wszystkich szczeblach oraz autorytatywnie podją decyzję o stworzeniu Krajowej Agencji Wywiadu i centralnego Ministerstwa Obrony. Dzięki tego rodzaju radykalnym działaniom wynikającym $\mathrm{z}$ „uprawnień bońskich” HR utrzymało zasadnicze znaczenie dla realizacji programu reform, a bośniackie elity polityczne, w obawie przed usunięciem z urzędu, liczyły się z instytucja Wysokiego Przedstawiciela. Natomiast następca P. Ashdowna - Christian Schwarz-Schilling - od momentu rozpoczęcia kadencji (1 lutego 2006-31 czerwca 2007) podkreślał, iż będzie wykorzystywać swoje uprawnienia sporadycznie i tylko w dwóch sytuacjach: „Gdyby pojawiło się zagrożenie dla pokoju lub bezpieczeństwa, albo gdyby podjęto próby podważania pracy Międzynarodowego Trybunału Karnego ds. Zbrodni w Byłej Jugosławii”19. Zgodnie z wypowiedziami Ch. Schwarza-Schillinga z lutego 2006 r., miał on nadzorować przejście od obecnego quasi-protektoratu do przejęcia pełnej odpowiedzialności przez podmioty lokalne oraz przekształcenia w ciagu roku HR w EUSR, włacznie ze zniesieniem „uprawnień bońskich”. Natomiast Bośnia i Hercegowina, niezależnie od braku postępów przy reformie policji, miała wejść na szlak prowadzący ja do stopniowej integracji z UE. Poprzez tego typu wypowiedzi, naciski na wprowa-

18 G. Ó Tuathail, Geopolitical Discourses: Paddy Ashdown and the Tenth Anniversary of the Dayton Peace Accords, „Geopolitics” 2006, vol. 11, s. 146.

19 Wywiad. Christian Schwarz-Schilling: Ostatni Wysoki Przedstawiciel w Bośni $i$ Hercegowinie, „Przegląd NATO”, [Wiosna] 2006, http://www.nato.int/docu/ review/2006/ issue1/polish/interview.html (dostęp 13 IV 2011). 
dzenie zapoczątkowanego przez P. Ashdowna procesu reform, które były wywierane przez lokalne elity, zostały zredukowane lub wręcz wyeliminowane. Ówczesny entuzjazm szybko okazał się przedwczesny, czego dowodem była dymisja Ch. Schwarza-Schillinga. Większość instytucji nadal pozostała bezużyteczna lub była w najlepszym przypadku na etapie wstępnego określania swoich kompetencji. W konsekwencji idea zreformowania starych instytucji lub też stworzenia nowych, wolnych od politycznego wpływu, załamała się.

Dość późno organizacje międzynarodowe zasiadające w PIC postanowiły stworzyć platformę konsultacji i koordynacji swoich działań. Powstała ona w $2002 \mathrm{r}$. jako tzw. Zarząd Dyrektorów (Board of Principals) i miała działać pod kierownictwem Wysokiego Przedstawiciela. W ramach tego forum starano się wzmocnić efektywność działań oraz przeciwdziałać powielaniu zadań poszczególnych instytucji. W skład Board of Principals weszli przedstawiciele: OHR, EUFOR, Kwatery Głównej NATO w Sarajewie, OBWE, UNHCR, EUPM i Komisji Europejskiej oraz takie międzynarodowe instytucje finansowe, jak Bank Światowy i Międzynarodowy Fundusz Walutowy ${ }^{20}$. Brakowało jednak pomysłu na przyszłość i strategicznego podejścia do sytuacji w Bośni i Hercegowinie. Tym samym przez długi okres nie udało się zidentyfikować żadnych konkretnych celów. Dopiero w 2003 r. stworzono tzw. Plan Implementacji Działań OHR ${ }^{21}$, który zawierał koncepcję realizacji zadań tylko na najbliższy rok, bez uwzględnienia długofalowych celów. Mankamentem tego planu było również to, iż jego priorytety zależały od osoby pełniącej funkcję HR, co negatywnie odbijało się na próbach stabilizacji i budowy instytucji państwowych ${ }^{22}$. Również różnorodne podejście do realizacji zadań poszczególnych Wysokich Przedstawicieli, charakteryzujące się przy realizacji poszczególnych celów raz próbą szukania kompromisu, a innym razem wymuszaniem decyzji poprzez użycie „uprawnień bońskich”, skutkowało dalszym pogłębieniem braku spójności politycznych koncepcji oraz podważaniem autorytetu społeczności międzynarodowej.

Kolejnym przykładem istniejacych problemów w zakresie koordynacji działań oraz braku strategicznego podejścia do stabilizacji Bośni i Hercegowiny była ogłoszona w grudniu 2006 r. redukcja wojsk EUFOR. Stwierdzono wówczas, iz sytuacja poprawiła się tak znacznie, że można zredukować siły militarne z 6,5 tys. do 2 tys. żołnierzy. Postanowiono też zamknać dotychczasowe bazy operacyjne $\mathrm{w}$ regionach, a wszystkie jednostki manewrowe skoncentrować w Sarajewie w bazie Camp Butmir. Biorąc pod uwagę fakt, iż Milorad Dodik, który został

${ }^{20}$ Board of Principals, 29 VII 2002, http://www.ohr.int/board-of-princip/default.asp? content_id=27551 (dostęp 23 II 2011).

${ }_{21}$ OHR Mission Implementation Plan, 30 I 2003, http://www.ohr.int/ohr-info/ohrmip/default.asp?content_id=29145 (dostęp 22 II 2011).

${ }_{22}$ Ch. Milotat, Tätigkeit der internationalen Akteure in Bosnien und Herzegowina, „Europäische Sicherheit” 2008, Heft 1, s. 17. 
premierem RS w lutym 2006 r., zainicjował wówczas kampanię na rzecz jej niepodległości i tym samym spowodował paraliż instytucji państwowych, decyzja o zmniejszeniu EUFOR mogła wydawać się wysoce nieodpowiedzialna. Wraz z postępującą redukcją wojsk, które stanowiły czynnik wspierający decyzje Wysokiego Przedstawiciela, zmniejszała się możliwość wywierania dalszego nacisku i presji przez obie te instytucje na elity lokalne. Z tego też powodu jednoczesne ogłoszenie zamiaru transformowania OHR w EUSR oraz redukcji wojsk EUFOR okazało się przedwczesne. Doprowadziło to do osłabienia urzędu HR i dalszej jego dysfunkcji, a tym samym do ignorowania go przez przedstawicieli Republiki Serbskiej ${ }^{23}$. Zaowocowało to zmniejszeniem zaangażowania i nacisku społeczności międzynarodowej, paraliżem reform, dymisja Ch. Schwarza-Schillinga i trudnościami w wykonywaniu mandatu przez kolejnego Wysokiego Przedstawiciela - Miroslava Lajčáka (1 lipca 2007-26 marca 2009). W tym kontekście nie powinno więc dziwić, że po piętnastu latach instytucja HR oraz pozostajace w jego dyspozycji „uprawnienia bońskie” nie sa w stanie zmusić bośniackich polityków do podjęcia całościowej reformy państwa.

W wyniku powyższych wydarzeń początkowe plany zamknięcia OHR zostały przesunięte w bliżej nieokreślona przyszłość. Dopiero w lutym 2008 r. Rada Zarządzająca PIC wydała decyzję uzależniająca zakończenie działalności urzędu Wysokiego Przedstawiciela oraz jego całkowite zastapienie przez Specjalnego Przedstawiciela UE (EUSR) od spełnienia następujacych warunków:

1) trwałego rozwiązania kwestii podziału własności między państwem a jego podmiotami;

2) trwałego rozwiązania problemu przynależności infrastruktury wojskowej;

3) uregulowania statusu dystryktu Brčko;

4) osiagnięcia stanu stabilności fiskalnej;

5) umocnienia praworządności.

Dodano również dwa specjalne warunki. Jeden z nich dotyczył podpisania Porozumienia o Stabilizacji i Stowarzyszeniu (SAA), co nastapiło w dniu 16 czerwca 2009 r. Drugi natomiast dotyczył stworzenia na bazie Porozumienia z Dayton stabilnej sytuacji politycznej, która zostałaby poddana ocenie PIC $^{24}$. Należy jednak zaznaczyć, iż określenie powyższych warunków dokonało się zbyt późno. W dodatku nastapiło to dopiero w konsekwencji poniesienia przez społeczność międzynarodową szeregu porażek, które związane były przede wszystkim $\mathrm{z}$ załamaniem w $\mathrm{BiH}$ procesu reform. W konsekwencji różnego rodzaju inicjatywy

${ }^{23}$ O. Rolofs, Bosnien-Herzegowina: Internationale Strategielosigkeit, „Europäische Sicherheit" 2010, Heft 5, s. 20

${ }^{24}$ Bosnia and Herzegovina 2008 Progress Report, 5 XI 2008, http://ec.europa.eu/ enlargement/pdf/press_corner/key-documents/reports_nov_2008/bosnia_herzegovina_progress_ report_en.pdf (dostęp 15 III 2011). 
M. Lajčáka, na rzecz przeprowadzenia kolejnych zmian, doprowadziły do osobistej frustracji, która zakończyła się jego rezygnacją ze stanowiska w styczniu 2009 r. Według niektórych opinii, pretekstem do uzasadnienia tego rodzaju kroku było przyjęcie przez niego funkcji ministra spraw zagranicznych Słowacji.

\section{Dayton czy Bruksela? Wyzwanie dla społeczności międzynarodowej}

Obecny ustrój Bośni i Hercegowiny, stworzony przez Dayton, doprowadził do niespotykanej rozbudowy aparatu biurokratycznego, w wyniku czego na obszarze tego kraju istnieje dziś 14 rządów i 180 ministerstw, których utrzymanie pochłania około $64 \%$ wydatków państwowych. Jednym z głównych problemów są zbyt wysokie koszty jednostkowe utrzymania urzędników. Jest to związane z ogromną nadwyżką zatrudnienia w stosunku do rzeczywistych potrzeb, która ma miejsce na wszystkich szczeblach władzy, zarówno centralnej, jak i poszczególnych podmiotów-entitetow oraz kantonów. W samej Federacji Bośni i Hercegowiny aż 70\% budżetu pochłania funkcjonowanie administracji, w konsekwencji czego brakuje środków finansowych na rozwój państwa i poszczególne inwestycje. Lokalni politycy nie podejmuja żadnych działań na rzecz zmiany zaistniałej sytuacji, bowiem nie leży to w ich interesie. Większość stanowisk obsadzana jest przez tzw. osoby z partii, czyli bądź to funkcjonariuszy partyjnych, bądź też zaufanych oraz wiernych wyborców. Sytuacja ta sprzyja utrzymaniu istniejącego stanu rzeczy w Federacji, gdzie partie rządzące unikają reform, które mogłyby doprowadzić do likwidacji systemu kantonów, czy też tylko zmniejszenia ich liczby ${ }^{25}$.

W tym też kontekście w 2003 r. Unia Europejska, zauważając mankamenty całości systemu określonego przez społeczność międzynarodową w Dayton, rozpoczęła w ramach procesu zbliżenia Sarajewa do struktur europejskich przywiązywać większą uwagę do przeprowadzenia w Bośni reformy, która pozwoliłaby na zastapienie dotychczasowej konfederacyjnej struktury państwa przez strukturę unitarna. Bruksela podjęła szereg działań majacych na celu zaktywizowanie swojej obecności w BiH oraz wzmocnienie pozycji EUSR. Już w 2003 r. P. Ashdown stwierdził, iż postanowienia z Dayton były podstawowym warunkiem zakończenia fazy wojny, ale jeśli nie zostaną one uzupełnione przez nowe koncepcje, to staną się główną przeszkodą na drodze do osiagnięcia kolejnego etapu. Znamienne jest tutaj jego stwierdzenie, że „Bośnia i Hercegowina potrzebuje reform konstytucyjnych w celu wprowadzenia do ery Brukseli, ale reforma ta musi opierać się na zasadzie konsensu i zostać w pełni zintegrowana

25 Bosnien Rekordhalter in Staatsausgaben, „Fokus Südosteuropa”, 20 V 2010, http://www.dw-world.de/dw/article/0,,5587841,00.html (dostęp 20 I 2011). 
z warunkami przystapienia do UE, co oznacza, że będzie to proces konstytucyjny" ${ }^{26}$. Ashdown słusznie zaznaczył, iż zmiany na lepsze nie powinny być wrogiem dotychczasowej polityki prowadzonej w ramach Porozumienia Pokojowego. Tym samym działania na rzecz implementacji postanowień z Dayton wymusiły na społeczności międzynarodowej konieczność postawienia sobie generalnego pytania o priorytety jej działalności. Dotyczyło to kwestii, co jest najważniejsze dla $\mathrm{BiH}$ : budowa funkcjonalnych instytucji państwowych i całkowite wdrożenie Porozumienia, czy też wprowadzanie zmian prowadzacych do integracji z Unia Europejska. Ponieważ urząd OHR poddawany był coraz ostrzejszej krytyce za swą dysfunkcjonalność i traktowany jako czynnik blokujący rozwój państwa, UE rozpoczęła działania w kierunku przeprowadzenia szeregu reform. Miało to doprowadzić do zastapienia „siły nacisku” Dayton przez „siłę przyciagania” Brukseli. W 2004 r. UE podpisała z Bośnią umowę ramową dotycząca zasad udziału w programach wspólnotowych. Natomiast w 10. rocznicę przyjęcia układu pokojowego z 1995 r. Bruksela zaproponowała rozpoczęcie rozmów w ramach Procesu Stabilizacji i Stowarzyszenia oraz otworzyła perspektywę członkostwa w Unii Europejskiej. Sukcesem było również uzyskanie przez BiH w styczniu 2006 r. Partnerstwa Europejskiego ${ }^{27}$. W dniu 15 maja 2006 r. Javier Solana i Olli Rehn rozpoczęli konsultacje z Radą Zarządzająca PIC, Wysokim Przedstawicielem Ch. Schwarz-Schillingiem oraz władzami Bośni i Hercegowiny w sprawie wzmocnienia obecności UE pod kątem planowanego zamknięcia OHR z dniem 30 czerwca 2007 r. Jednocześnie określili oni cele polityczne UE. Zadaniem długoterminowym miało być zapewnienie stabilnej, sprawnie funkcjonujacej, pokojowej i wieloetnicznej Bośni i Hercegowiny oraz jej pokojowa współpraca z sasiadami. Za cele średniookresowe uznali wspieranie postępów Sarajewa $\mathrm{w}$ integracji z UE, czemu służyć miało wdrażanie Porozumienia o Stabilizacji i Stowarzyszeniu oraz budowa skutecznych i funkcjonalnych struktur państwowych. Celem krótkoterminowym było zapewnienie skutecznego przejścia z poziomu odgórnego zarządzania z pozycji OHR na poziom zwiększonej lokalnej odpowiedzialności bośniackich elit, która miała być wspierana przez wzmocniona, spójną i jednolitą obecność UE. Służyć miała temu również redukcja roli EUFOR.

Bruksela postanowiła również wzmocnić stabilność BiH oraz wesprzeć jej suwerenność i integralność terytorialna, m.in. poprzez doprowadzenie do głębokiej reformy konstytucyjnej ${ }^{28}$. Ponadto wzmocnienie pozycji UE miało się

${ }^{26}$ G. Ó Tuathail, $d z$. cyt., s. 152.

${ }^{27}$ D. Wybranowski, Bośnia $i$ Hercegowina wobec Unii Europejskiej - trudna droga ku stowarzyszeniu. Problemy i wyzwania polityki UE na Bałkanach Zachodnich na poczqtku XXI wieku, ,Wrocławskie Studia Politologiczne” 2009, nr 10, s. 228.

28 Summary Note on the Joint Report by Javier Solana, EU High Representative for the CFSP, and Olli Rehn, EU Commissioner for Enlargement, on a Reinforced EU Presence in Bosnia and Herzegovina, Brussels, 17 XI 2006, S286/06, http://www.consilium.europa. eu/ueDocs/cms_Data/docs/pressdata/EN/ reports/91339.pdf (dostęp 20 II 2011). 
odbyć poprzez wspomniane zamknięcie Biura Wysokiego Przedstawiciela i zastapienie go Specjalnym Przedstawicielem UE o jasno sprecyzowanym mandacie i określonych zadaniach. Zakres obowiązków EUSR miał oscylować wokół kwestii politycznych i bezpieczeństwa. Specjalny Przedstawiciel, usytuowany w Delegacji Komisji Europejskiej w Sarajewie, z założenia miał doradzać oraz wspierać procesy związane z ustanowieniem rządów prawa, restrukturyzacja policji, walką z przestępczością zorganizowana, a także uczestniczyć w rozwijaniu współpracy z Międzynarodowym Trybunałem Karnym dla byłej Jugosławii. Działania UE oraz zamknięcie Biura Wysokiego Przedstawiciela miały przyczynić się do osiagnięcia zwiększonych efektów w przeprowadzeniu reform i stabilizacji państwa ${ }^{29}$.

Mimo wysiłków i pewnych postępów, jakie osiagnięto w latach 2004-2005 przy przeprowadzeniu reformy konstytucyjnej, policji, sądownictwa oraz fiskalnej ${ }^{30}$, sytuacja zmieniła się diametralnie w lutym 2006 r., kiedy premierem RS został M. Dodik. Jego obstrukcyjne działania doprowadziły w ciagu dwóch lat do paraliżu instytucji ogólnopaństwowych. Jednocześnie polityka UE ugruntowała wśród elit politycznych Bośni przekonanie, iż możliwe jest przystapienie do struktur unijnych bez zmiany konstytucji, czyli części zapisów Porozumienia z Dayton. Sytuację utrudniał fakt, iż w polityce Brukseli nie było jasnego sygnału, iż warunkiem przystapienia do UE jest reforma ustawy zasadniczej.

Wobec paraliżu struktur państwowych oraz fiaska zamknięcia OHR z końcem 2007 r., Unia Europejska postanowiła w okresie 2008-2009 jeszcze bardziej zwiększyć swoje zaangażowanie w regionie. Po podpisaniu Porozumienia o Stabilizacji i Stowarzyszeniu w czerwcu 2008 r. planowano wzmocnić instytucję EUSR, a jego mandat przeorganizować już od 2009 r. w zależności od sytuacji w Bośni. Zakładano, iż rezolucja Rady Bezpieczeństwa ONZ miałaby znieść urząd Wysokiego Przedstawiciela, pozostawiając dalsze postanowienia z Dayton w swojej mocy. Aktywna i kompleksowa polityka wobec Bośni miała opierać się na użyciu wszelkich możliwych instrumentów i mechanizmów, które wzmocniłyby działania obliczone na integrację z Unią. Swoistymi kołami zamachowymi reform miały być poszczególne porozumienia, jak Partnerstwo Europejskie oraz Porozumienie o Stabilizacji i Stowarzyszeniu, a także europejska misja policyjna i wojskowa. Do zamknięcia OHR i zbliżenia BiH z UE miało dojść niezależnie od postępów przy wprowadzaniu reform konstytucyjnych. Niemniej ramy ustawy zasadniczej musiały docelowo ewoluować w kierunku takiego zapisu, który zapewniłby skuteczne funkcjonowanie struktury państwowej oraz spójność działań na rzecz integracji z Unią. Reforma miała

${ }^{29}$ Tamże.

${ }_{30}$ Communiqué by the PIC Steering Board, PIC SB Political Directors, 7 X 2005, http://www.ohr.int/pic/default.asp?content_id=35654 (dostęp 11 II 2011). 
być wsparta przez Brukselę poprzez instytucje doradcze i odpowiednie środki finansowe ${ }^{31}$.

Mimo fiaska realizacji reformy policji w ramach tzw. Pakietu Kwietniowego z 2006 r., niemożności przeprowadzenia reform konstytucyjnych zawartych w tzw. Porozumieniu z Prud (listopad 2008 r.) oraz postępującego kryzysu struktur państwowych, udało się w październiku 2009 r. dwukrotnie doprowadzić do rozmów pomiędzy przedstawicielami najważniejszych ugrupowań politycznych $\mathrm{BiH}$. Spotkania, do których doszło w bazie wojskowej Camp Butmir w Sarajewie, należy zawdzięczać inicjatywie i działaniu przewodniczącego prezydencji UE Carlowi Bildtowi, Komisarzowi Unii ds. rozszerzenia O. Rehnowi oraz amerykańskiemu zastępcy sekretarza stanu Jimowi Steinbergowi. Same rozmowy miały na celu uzyskanie akceptacji Serbów, Chorwatów i Muzułmanów dla dalszych reform, jako warunku przystapienia do struktur euroatlantyckich ${ }^{32}$. Dotyczyły one takich kwestii, jak: regulacja własności państwowej, zmiany w konstytucji, warunki zamknięcia OHR oraz kryteria konieczne do liberalizacji ruchu wizowego. Zakończyły się one niepowodzeniem, jednak nie można całkowicie za ten stan rzeczy obwiniać przedstawicieli poszczególnych narodowości. Zastrzeżenia budzą już sam sposób i forma przeprowadzenia tego spotkania. Podważyły one autorytet społeczności międzynarodowej, w tym zasadność strategii przyjętej przez szwedzką prezydencję oraz kompetencję Brukseli w zakresie kształtowania wspólnej polityki zagranicznej. W pierwszej kolejności szczególnej krytyce poddano miejsce spotkania, czyli silnie strzeżoną i odizolowaną od mediów bazę wojskowa, co całkowicie wykluczyło możliwość prowadzenia otwartej i pozbawionej nacisków debaty na temat dalszego kształtu państwa. Społeczeństwo bośniackie zostało wyłączone $\mathrm{z}$ tej tak ważnej dla kraju dyskusji. Ponadto spotkanie w Butmir było inicjatywa przedstawicieli prezydencji szwedzkiej UE i USA. Wysoki Przedstawiciel został wyłączony z tej inicjatywy i zaproszony tylko w charakterze gościa, jako EUSR, co podważyło jego autorytet.

Rozmowy w Butmir unaoczniły również niekonsekwencję w polityce UE, która jeszcze w listopadzie $2008 \mathrm{r}$. twierdziła, że reforma konstytucji nie jest warunkiem przystapienia do UE, by rok później zmienić zdanie. Nic więc dziwnego, iż w takiej sytuacji społeczność międzynarodowa nie była w stanie

${ }^{31}$ Summary Note on the Joint Report by Javier Solana, EU High Representative for the CFSP, and Olli Rehn, EU Commissioner for Enlargement, on "EU'S Policy in Bosnia and Herzegovina: the Way Ahead", Brussels, 10 X 2008, S367/08, http://www.eu2008.fr/ webdav/site/PFUE/shared/import/1110_cagre_defense/EU_policy_in_bosnia_and_Herzegovina_ joint_report_solana_rehn_en.pdf (dostęp 20 I 2010).

32 Jak powiedział po spotkaniu C. Bild: ,We have come here in order to say to the leaders of Bosnia that now is really the time to join the rest of the region in moving forward with European, Euro-Atlantic integration" - International effort aims to defuse BiH tensions, 12 X 2009, http://www.setimes.com/cocoon/setimes/xhtml/en_GB/features/setimes/ features/2009/10/12/feature-01 (dostęp 14 II 2011). 
zapobiec szerzeniu się nacjonalistycznej retoryki M. Dodika, który nie tylko opowiedział się za likwidacją OHR, ale również zażądał wprowadzenia do konstytucji zapisów o prawie Republiki Serbskiej do secesji i rozpisania w tej sprawie referendum.

O braku wspólnej strategii i koordynacji działań podczas spotkania z Butmir świadczy też wystapienie Sekretarza Generalnego NATO Fogha Rasmussena. Stwierdził on mianowicie, że co prawda chętnie widziałby postępy w rozmowach politycznych, to jednak nie ma żadnego związku pomiędzy wynikami procesu z Butmir a przystapieniem Bośni do Planu Działań na Rzecz Członkostwa w Sojuszu Północnoatlantyckim (MAP). W tym przypadku aplikacja do NATO miała odbywać się bowiem na bazie oceny zdolności Sarajewa do wypełnienia warunków postawionych przez Sojusz Północnoatlantycki ${ }^{33}$. Stanowisko to, przedstawione dopiero $\mathrm{w}$ dwa miesiące po zakończeniu rozmów w Butmir, należy uznać za formę opowiedzenia się przez NATO za utrzymaniem indywidualnego, niezależnego od działań podejmowanych przez inne organizacje czy też poszczególne państwa, podejścia do procesu integracji $\mathrm{BiH}$ ze strukturami euroatlantyckimi. Tym samym było to swego rodzaju potwierdzenie fiaska działań podjętych przez UE i USA.

Butmir uwidocznił również problemy, z którymi zmaga się Wysoki Przedstawiciel. Okazało się, iż nie tylko odmienne stanowisko poszczególnych narodowości $\mathrm{BiH}$ co do przyszłości urzędu HR stanowi największe wyzwanie, ale przede wszystkim brak zdecydowania, jednomyślności i koordynacji działań członków Rady ds. Wdrażania Pokoju przy rozwiązywaniu tego problemu. Generalnie wśród członków PIC panuje opinia, iż „uprawnienia bońskie” nie maja już żadnego zastosowania i należy zmniejszyć obecność międzynarodową w tym kraju tak, aby BiH mogła stanąć na własnych nogach. Właściwie żaden z członków PIC (poza Turcja) nie umiejscawia problemu Bośni wśród priorytetów polityki zagranicznej, co w konsekwencji przekłada się na swego rodzaju brak woli działania członków Rady ds. Wdrażania Pokoju. Sytuację komplikuja dodatkowo podziały istniejące pomiędzy USA, UE i Rosja, jak również brak zgodności w tej kwestii wśród państw UE. Stany Zjednoczone opowiadają się za utrzymaniem dotychczasowej pozycji OHR i jego „uprawnień bońskich”, co miałoby zapobiec dalszemu łamaniu Porozumienia Pokojowego z Dayton. Tym samym prowadzą politykę sprzeczna z fundamentalnym dogmatem unijnym, zakładającym, iż warunkiem integracji z UE jest zamknięcie wszelkich instytucji międzynarodowych dysponujących zbyt dużą władzą wykonawczą. W Brukseli panuje opinia, iz kompetencje Wysokiego Przedstawiciela są niedemokratyczne, należy je znieść i w pełni zastapić nowym mandatem EUSR. Jednak nie

${ }^{33}$ Rasmussen: There is no Connection between Butmir Process and Map, 2 XII 2009, http://www.emg.rs/en/news/region/106039.html (dostęp 12 II 2011). 
wszystkie państwa UE są przekonane, iż pełna transformacja OHR w EUSR i siła integracyjna Unii są wystarczającym bodźcem do przeprowadzenia reform dla i tak już etnicznie podzielonych lokalnych elit politycznych. Ta grupa, reprezentowana przez Wielką Brytanię, Holandię, Belgię, Danię i Irlandię oraz wspierana przez Turcję i USA, wyraża potrzebę jasnego określenia warunków, które byłyby konieczne do zniesienia międzynarodowej władzy wykonawczej (OHR i EUFOR). Jeszcze innego zdania jest Rosja, która forsuje politykę likwidacji OHR i przeprowadzenia referendum w sprawie niepodległości Republiki Serbskiej ${ }^{34}$. Powyższe wewnętrzne tarcia w UE i różnica interesów pomiędzy nią a USA co do polityki wobec Bośni i Hercegowiny, stały się też powodem fiaska działań społeczności międzynarodowej w Butmir. Celem Waszyngtonu było zapoczątkowanie procesu reform, a nie zniesienie funkcji Wysokiego Przedstawiciela. Natomiast Bruksela liczyła na zamknięcie i likwidację jego urzędu. Dlatego też OHR wystapił tam tylko i wyłącznie w charakterze EUSR. Ten brak koordynacji w działaniach społeczności międzynarodowej został więc po raz kolejny świetnie wykorzystany przez M. Dodika ${ }^{35}$.

Innym przykładem na brak konsekwencji społeczności międzynarodowej przy realizacji cywilnych aspektów Porozumienia z Dayton oraz niespójność strategii prezentowanej przez OHR i UE, jest reforma policji ${ }^{36}$. W 2005 r., w ramach procesu restrukturyzacji policji, urząd HR ogłosił dziesięć powodów, dla których ważne było przeprowadzenie reformy tej formacji mundurowej. Oprócz takich kwestii, jak gwarancja bezpieczeństwa dla obywateli czy walka z przestępczością zorganizowana, wyraźnie podkreślono, iż jest ona wymogiem do członkostwa w UE. Zaznaczono też, iż „bez restrukturyzacji policji, nie będzie możliwe wprowadzenie żadnych zmian w europejskich przepisach wizowych dla obywateli Bośni i Hercegowiny"37. Początkowo działania te były w pełni wspierane przez UE, która w raporcie Komisji Europejskiej z 2003 r. reformę policji uznała za warunek konieczny do rozpoczęcia negocjacji i podpisania Porozumienia o Stabilizacji i Stowarzyszeniu ${ }^{38}$. Przez dłuższy czas wskazywała ona również

${ }_{34}$ K. Bassuener, What Next in Bosnia?, 22 X 2009, http://www.boell.de/ worldwide/europenorthamerica/europe-north-america-7682.html (dostęp 14 II 2011).

${ }_{35}$ Tenże, The International Community in Bosnia and Herzegovina - Experiment without a Strategy, [w:] Bosnia and Herzegovina: Between EU-integration Toolbox and International Community's Exit Strategy, Sarajevo 2010, s. 52.

${ }_{36}$ P. Sokołowska, Policja jako przykład niewydolności systemu bezpieczeństwa narodowego w Bośni i Hercegowinie, „Rocznik Bezpieczeństwa Międzynarodowego” 2010/2011, s. $269-283$.

3710 Reasons For Police Restructuring, 17 III 2005, http://www.ohr.int/ohr-dept/ruleof-law-pillar/prc/default.asp?content_id=34262 (dostęp 15 III 2011).

${ }^{38}$ Report from the Commission to the Council on the Preparedness of Bosnia and Herzegovina to Negotiate a Stabilization and Association Agreement with the European Union, 
na postępy w przeprowadzaniu reform, podczas gdy nie zostały one w pełni osiagnięte. Brak konsekwencji polegał jednak na tym, iż mimo wytycznych OHR oraz polityki warunkowości Brukseli, w 2008 r. zostało podpisane Porozumienie o Stabilizacji i Stowarzyszeniu. Ogłoszono wówczas, iż parlament BiH przyją odpowiednie Prawo o Niezależności Organów Nadzorujacych Struktury Policyjne, Prawo o Dyrektoriacie ds. Koordynacji Organów Policyjnych oraz o Agencjach do Spraw Wsparcia Policji BiH, co uznano za wprowadzenie długo oczekiwanej reformy. W rzeczywistości były to powierzchowne zmiany, tworzace szereg nowych instytucji koordynacyjnych i doradczych, a niedotykajacych sedna problemu. Nie wprowadzały koniecznej i oczekiwanej centralizacji struktur policyjnych oraz innych agencji wymuszajacych przestrzeganie prawa. Wiele reform na poziomie państwowym, jak np. reforma służb specjalnych, zostało co prawda oficjalnie przeprowadzonych, jednak w praktyce przyjęte rozwiązania nadal nie funkcjonuja. Ponadto całość procesu jest dotknięta problemami etnicznymi. Instytucje stworzone przez Wysokiego Przedstawiciela, takie jak SIPA, Straż Graniczna i Ministerstwo Bezpieczeństwa, nie tylko nie działaja w sposób odpowiedni do założen, ale także nie posiadają odpowiedniego autorytetu wśród konstytucyjnych narodów Bośni i Hercegowiny. Te problemy nie stanęły jednak na przeszkodzie przy liberalizacji rynku wizowego, którą UE wprowadziła w grudniu 2010 r. Powyższe działania po raz kolejny osłabiły nie tylko urząd Wysokiego Przedstawiciela, ale także podważyły autorytet Brukseli. Potwierdzaja to wypowiedzi pracowników instytucji unijnych w Bośni, którzy stwierdzaja wprost, iż w działaniach UE dominuje przede wszystkim potrzeba sukcesu. Jest to efekt ośmioletniej obecności Misji Policyjnej EUPM - pierwszej cywilnej operacji realizowanej przez Unię. Dlatego też bardzo mocno rozgłaszane są wszelkiego rodzaju, choćby nawet pozorne, sukcesy w przeprowadzaniu reform. Pozwala to bowiem Unii z jednej strony zachować twarz, z drugiej zaś zakończyć misję z końcem 2011 r., uznając ją za sukces.

Kolejnym przykładem na brak zdecydowania w podejściu społeczności międzynarodowej do kwestii przyszłości BiH jest sytuacja wewnętrzna w samej Unii Europejskiej, związana z wejściem w życie Traktatu z Lizbony, który powołuje Europejską Służbę Działań Zewnętrznych. Powstanie tej instytucji, wraz z ustanowieniem urzędu Wysokiego Przedstawiciela ds. Zagranicznych i Polityki Bezpieczeństwa, stawia pod znakiem zapytania przyszłość urzędu Specjalnego Przedstawiciela UE w Bośni i Hercegowinie oraz w innych regionach świata. Dotychczas nie została wypracowana jasna koncepcja i wizja dalszej działalności EUSR w nowych warunkach po Traktacie z Lizbony i po osiagnięciu zdolności funkcjonowania przez Europejską Służbę Działań Zewnętrznych. Na mocy decyzji

Brussels, 18 XI 2003, COM (2003) 692 final, s. 41, http://www.esiweb.org/pdf/bridges/bosnia/ EU_Feasiblity_study.pdf (dostęp 10 III 2011). 
Rady UE z 11 sierpnia 2010 r., postanowiono zlikwidować z dniem 28 lutego 2011 r. cztery stanowiska EUSR: w Macedonii, na Bliskim Wschodzie, w Gruzji i Mołdawii ${ }^{39}$. Jak dotąd, urzędy te udało się zamknąc tylko w Mołdawii i Gruzji. Natomiast innym EUSR przedłużono okres mandatu do 31 sierpnia $2011 \mathrm{r}$. Ta sytuacja pokazuje, iż w samej Brukseli brakuje jasnych wytycznych co do przyszłości Specjalnych Przedstawicieli UE, bowiem Traktat z Lizbony tylko w art. 33 wspomina o tej funkcji. Zgodnie z jego zapisem „Rada może, na wniosek Wysokiego Przedstawiciela Unii do Spraw Zagranicznych i Polityki Bezpieczeństwa, mianować Specjalnego Przedstawiciela, któremu powierza się mandat w odniesieniu do poszczególnych spraw politycznych. Specjalny przedstawiciel w sprawowaniu swojego mandatu podlega Wysokiemu Przedstawicielowi" 40 . Określenie sensu dalszego istnienia EUSR wydaje się szczególnie istotne pod kątem powoływania w miejscu dotychczasowych delegatur tzw. ambasad UE. $\mathrm{W}$ tej sytuacji utrzymywanie funkcji Specjalnego Przedstawiciela w aktualnym kształcie może wydawać się anachronizmem, bowiem nie ma to nic wspólnego z forsowaną przez Brukselę polityką spójnych działań zewnętrznych ${ }^{41}$. Sytuację tę komplikuje fakt, iż niektóre z państw członkowskich Unii Europejskiej obawiają się, iz rozszerzenie kompetencji przyznanych Catherine Ashton i Europejskiej Służbie Działań Zewnętrznych może w praktyce spowodować redukcję kompetencji państw członkowskich $\mathrm{w}$ zakresie polityki zagranicznej. Jest to związane z generalnym pytaniem, czy silna Europejska Służba Działań Zewnętrznych nie spowoduje zamknięcia dotychczasowych placówek państw członkowskich UE.

W tym też kontekście, w piętnaście lat po Dayton pojawia się pytanie nie tylko o przyszłość OHR, ale również o przyszłą rolę Specjalnego Przedstawiciela UE. Dyskusje na ten temat zapoczątkowało ujawnienie informacji o tajnym dokumencie dotyczącym przyszłości pozycji UE w Bośni i Hercegowinie. Dokument ten pt. Kolejne kroki w Bośni i Hercegowinie poprzez silniejsza obecność $i$ wzmocniona politykę $U E^{42}$, przygotowany przez C. Ashton, ujrzał światło dzienne w lipcu $2010 \mathrm{r}$. Na czterech stronach została przedstawiona koncepcja zunifikowanej obecności UE w BiH. Zakłada ona połączenie w ramach jednej instytucji - Delegacji UE, działań Komisji i EUSR. Szef Delegacji, jako

${ }^{39}$ D. Liszczyk, Specjalni przedstawiciele UE $w$ nowej architekturze instytucjonalnej Wspólnej Polityki Zagranicznej i Bezpieczeństwa, „Biuletyn [PISM]”, 6 IX 2010, nr 115, s. 2, http://www.pism.pl/biuletyn/files/20100906_723.pdf (dostęp 15 III 2011).

40 Traktat z Lizbony, art. 33, http://bookshop.europa.eu/is-bin/INTERSHOP.enfinity/ WFS/EU-Bookshop-Site/pl_PL/-/EUR/ViewPublication-Start?Publication Key=QC3209190 (dostęp 15 III 2011).

${ }^{41}$ D. Liszczyk, $d z$. cyt.

${ }^{42}$ Next Steps in Bosnia and Herzegovina through Stronger EU Presence and a Reinforced EU Policy (wersja niemiecka: Nächste Schritte in Bosnien und Herzegowina durch eine stärkere EU-Präsenz und eine verstärkte EU-Politik). 
Specjalny Przedstawiciel UE, mógłby rekomendować Radzie UE skrócenie pomocy przedakcesyjnej, wprowadzenie zakazu wydawania wiz oraz zamrożenie aktywów. Mogłoby to nastapić w przypadku naruszenia Porozumienia z Dayton lub też dla wymuszenia reform konstytucyjnych ${ }^{43}$. Dokument ten jednocześnie ujawnił kolejną dyskusję toczoną wśród państw UE na temat kompetencji nowego Specjalnego Przedstawiciela i jednocześnie szefa Delegacji UE, a zarazem ambasadora Brukseli w Sarajewie. Sytuację tę komplikuje dodatkowo fakt, że w przeciwieństwie do daty zakończenia sprawowania urzędu przez Valentina Inzko w ramach mandatu Specjalnego Przedstawiciela UE - EUSR (sierpień 2011 r.), nieznana jest data zamknięcia urzędu Wysokiego Przedstawiciela.

Nadal nie ma też żadnych konkretnych informacji na temat rzeczywistych kompetencji nowego EUSR oraz brakuje wśród państw członkowskich UE kompromisu co do zakresu jego uprawnień. Niektórzy przedstawiciele uważaja, iż w momencie zamknięcia OHR Bruksela, jako motor integracji europejskiej, mogłaby mieć większą siłę oddziaływania na sytuację w BiH. Jednak inne kraje, jak np. Wielka Brytania, uważaja, iż nowy EUSR powinien mieć konkretną władzę w sytuacji naruszania prawa. Decyzje te muszą być jednak zharmonizowane z pozycją Rady ds. Wdrażania Pokoju i rozstrzygnięte jak najszybciej, tak aby nie doszło do sytuacji, w której jednocześnie działają obok siebie - OHR oraz silny kompetencyjnie i odrębny personalnie przedstawiciel UE w Bośni. W konsekwencji uznaje się, iż najpierw powinna zostać rozwiązana jedna instytucja, a następnie powołana druga, która mogłaby tym samym przejąć jej nowe obowiąki. W przeciwnym razie brak tego rodzaju restrukturyzacji i uzgodnienia jasnego stanowiska w ramach UE i PIC, może doprowadzić do dalszego kryzysu politycznego.

Powyższe różnice oraz to, iż nadal nie wiadomo, czy szef Delegacji będzie Specjalnym Przedstawicielem, to jeden z powodów, dlaczego Brukseli od lipca 2010 r. nie udało się wyznaczyć kandydata, który stanąłby na czele Delegacji UE w Sarajewie. Kolejnym wyzwaniem dla UE będzie uzyskanie zgody społeczności międzynarodowej, reprezentowanej przez pięćdziesięciu pięciu członków PIC, co do przyszłości urzędu Wysokiego Przedstawiciela. Jak do tej pory różnice zdań w PIC doprowadzały do przedłużenia jego mandatu, niezależnie od tego, czy UE miała przejać jego funkcje w 2005 r. ${ }^{44}$ Brak decyzji w sprawie zamknięcia OHR jeszcze bardziej skompromituje działania UE i PIC oraz załamie cały dotychczasowy plan polityczny Brukseli w stosunku do Bośni i Hercegowiny. Tym samym

43 B. Waterfield, Baroness Ashton Moves to Take Control of Bosnia, 27 VII 2010, http://www.telegraph.co.uk/news/worldnews/europe/bosnia/7912675/Baroness-Ashtonmoves-to-take-control-of-Bosnia.html (dostęp 22 II 2011); K. Bassuener, The International Community..., s. 52-53.

${ }_{44}^{4}$ T. Vogel, Ministers Delay Talks on the Future of EU's Envoy in Bosnia, 20 I 2011, $\mathrm{http} / / / \mathrm{www}$.europeanvoice.com/article/imported/ministers-delay-talks-on-the-future-of-eu-senvoy-in-bosnia-/69972.aspx (dostęp 20 II 2011). 
pod znakiem zapytania stanie droga Sarajewa do UE. Wątpliwe wydaje się, aby Unia bez wsparcia OHR, Rosji i USA była w stanie sama narzucić bośniackim elitom politycznym takie rozwiązania ustrojowe, dzięki którym państwo to mogłoby samodzielnie funkcjonować. Jest to tym bardziej dyskusyjne, iż od $2006 \mathrm{r}$. obserwuje się generalne zmęczenie sytuacją na Bałkanach i coraz większy brak zainteresowania państw członkowskich UE tym regionem. Świadczy o tym choćby plan zamknięcia misji EUPM pod koniec 2011 r. oraz powolny proces redukcji wojsk EUFOR.

\section{Wnioski}

Ogólny brak wizji, mała skłonność do kompromisu oraz niezdolność do podjęcia konkretnych decyzji przez wspólnotę międzynarodową odnośnie do przyszłości OHR/EUSR, nie sprzyja szybkiemu rozwiązaniu i tak już skomplikowanej sytuacji wewnętrznej w Bośni i Hercegowinie. Po wyborach z 3 października 2010 r. jak dotąd tylko Republice Serbskiej udało się stworzyć koalicję rządowa. To, że ani UE, ani OHR w kilka miesięcy po tym wydarzeniu nie udało się wpłynąć na polityków bośniackich, aby utworzyli rząd na szczeblu Federacji i całości państwa, potwierdza ogólny kryzys działań międzynarodowych, jak również pełne rezerwy podejście lokalnych elit do apeli Brukseli czy też Waszyngtonu. Nie wydaje się, aby najnowsze pomysły, zawarte $\mathrm{w}$ dokumencie $\mathrm{z}$ marca 2011 r. pt. Dokument o możliwości wprowadzenia środków ograniczajacych wobec osób fizycznych $i$ prawnych $w$ zwiazku $z$ sytuacja $w$ Bośni $i$ Hercegowinie ${ }^{45}$, uzyskały poparcie wszystkich członków UE i doprowadziły do pozytywnych zmian. Zakładaja one bowiem dość radykalne kroki, które mają obejmować możliwość nałożenia sankcji, zablokowania pomocy finansowej, wprowadzenia zakazu podróży i „cichej” izolacji osób oraz poszczególnych instytucji.

Obecny kryzys wywołany brakiem jasności co do dalszych losów OHR/EUSR i pozycji UE w regionie, nie jest juz tylko determinowany obstrukcyjna polityka M. Dodika, ale w równej mierze także zachowaniem społeczności międzynarodowej, które doprowadziło do stagnacji i paraliżu struktur państwowych Bośni. Fiasko „polityki warunkowości” prowadzonej przez Brukselę potwierdzaja nie tylko nieudane próby mediacji podejmowane przez V. Inzko, ale też brak sukcesu specjalnej misji M. Lajčáka (od grudnia 2010 r. Dyrektora Zarządzającego ds. Bałkanów Zachodnich, Rosji, Europy Wschodniej w Europejskiej Służbie Działań Zewnętrznych). W lutym 2011 r. udał się on bowiem do Bośni i Hercegowiny

${ }^{45}$ Brussels Creates List of Sanctions for BiH Politicians!, European Union Police Mission, „PPIO Daily Media Summary” 15 III 2011, http://www.eupm.org/Detail.aspx?ID $=1653 \& \mathrm{TabID}=5$. 
w celu podjęcia rozmów z przedstawicielami najważniejszych partii tego kraju na temat kryzysu rządowego i przerwania impasu politycznego ${ }^{46}$. W tej sytuacji mało prawdopodobne wydaje się zlikwidowanie urzędu Wysokiego Przedstawiciela i całkowite przejęcie jego kompetencji przez EUSR lub też ambasadora UE w Sarajewie. Zniesienie HR na obecnym etapie kryzysu politycznego i przy obecnym braku zdecydowania, panującym wśród społeczności międzynarodowej, spowodowałoby, iż nawet formalnie żadna instytucja międzynarodowa nie utrzymałaby pozycji dominującej $\mathrm{w}$ stosunku do struktur administracyjnych i państwowych BiH. Groziłoby to podważeniem wyników dotychczasowych reform, podejmowanych przez ostatnie piętnaście lat, i tym samym mogłoby doprowadzić do stopniowej destabilizacji państwa.

Brak ogólnej strategii międzynarodowej i niewystarczająca koordynacja działań pomiędzy członkami PIC skutkuje dalszym osłabieniem instytucji międzynarodowych. Obserwując politykę Unii wobec Bośni i Hercegowiny, należy stwierdzić, iż zawiodła przede wszystkim wiara w „siłę przyciagania” Brukseli, która kreując wizję integracji $\mathrm{BiH}$ z Unią Europejską miała doprowadzić do ustabilizowania sytuacji politycznej w tym kraju. Plany te okazały się nie w pełni spójne i mało atrakcyjne dla lokalnych elit. Zbyt mocno koncentrowano się na przejęciu od OHR przez misję UE w Bośni pełni kompetencji, nie zastanawiając się w ogóle nad tym, jakie warunki powinny być spełnione, żeby do tego doszło. Brak konsekwentnej i zdecydowanej polityki oraz rozwiązania ad hoc przyniosły skutki odwrotne do zamierzonych. Nie wydaje się, aby obecna polityka Unii, opierająca się na możliwości nałożenia na $\mathrm{BiH}$ sankcji, przyniosła lepsze efekty od dotychczasowych i to w sytuacji i tak już mocno nadszarpniętego autorytetu Brukseli w tym kraju.

${ }^{46}$ EU's Lajcak Heads to Bosnia as Deadlock Drags On. EU Envoy Miroslav Lajcak to Launch a New Round of Negotiations with Bosnia's Political Leaders as Deadlock Continues in the Country, 23 II 2011, www.balkaninsight.com/en/article /eu-s-lajcak-headsto-bosnia-as-deadlock-drags-on (dostęp 15 III 2011). 